\title{
1. Introduction to the Handbook on Gender and Public Administration
}

\author{
Patricia M. Shields and Nicole M. Elias
}

\section{INTRODUCTION}

This is a liminal time for the study of gender and public administration (PA). Only a few decades ago, this field focused almost solely on integration of women. It is now moving toward a field of study that incorporates equity issues surrounding gender identity, sexual orientation, the non-binary experience and intersectionality. Voices calling for social equity diversity and inclusion are urgent and often include young practitioners and scholars. It is a time of redefinition, renewal, re-drawing or reimagining conceptual boundaries of the field. We are revisiting wicked problems surrounding gender equity with new questions and approaches. It is also a kind of transition space between generations. A first generation set of scholars are working with and learning from a new energetic generation. Actually, the co-editors of this volume capture the intergenerational transition that is happening.

It is time for a handbook that can tell the stories of gender and public administration. This chapter and book capture this liminality by revealing the multiple and evolving dimensions of gender and public administration. It shows how we got here and clarifies where we are heading as a field. This focus on gender is part of a larger trend in public administration zeroing in on long-neglected social equity concerns. Amidst calls for greater inclusion of gender content in public administration pedagogy and scholarship, the ruptures in our system revealed by COVID-19 serve as a focusing event with implications for gender equity in policy and administration.

Gender is a critical, yet under-developed lens for understanding public administration and policy. This Handbook on Gender and Public Administration (hereafter Handbook) takes a holistic view of gender that seriously engages its multiple dimensions, especially issues that are beyond the binary. This Handbook provides a collection of work to draw greater attention to gender in the field including pressing gender topics such as the pay gap, workplace protections and public policies addressing different genders. Written just before and completed after the onset of COVID-19, this edited volume recognizes the significant impact gender has on the public sector. As a focusing event, COVID-19 exposes gender stereotypes and inequitable outcomes along gender lines that prompt the need for serious examination of the gender dimension of public administration and policy.

This chapter introduces the Handbook and covers both the theory and practice of public administration and policy. It also details the evolution of gender in the public sector, tracing the expansive and evolving understanding of gender identities that influence and are influenced by public administration and policy. It begins by tracing the historical context. First, the early history of public administration and the role of women in this history are briefly reviewed. Special emphasis is placed on the important and buried role of a social justice infused model of public administration developed by women during the late nineteenth and early twentieth cen- 


\section{Handbook on gender and public administration}

turies. Second, gender is considered within the modern era by focusing on public administration as a profession using the establishment of the American Society for Public Administration as a landmark event. The chapter then switches to summarizing the content and contributions of the remaining 26 chapters of the Handbook. These chapters are organized into three Parts: Theoretical and Historical Roots, Pillars of Public Administration, and Contexts of Gender and Public Administration. We conclude with a section that demonstrates the utility of "seeing" gender in public administration, using COVID-19 as a focusing event that brought gender to the forefront of public agendas, particularly in the realm of child care.

\section{EVOLUTION OF GENDER IN PUBLIC ADMINISTRATION}

For millennia governments have developed policies and employed public administrators to carry out their goals. This was a world where gender was dichotomized and rigidly defined as male and female. Men owned the public sphere and the work we would recognize as public administration. Most women lived and worked in the private sphere where they cared for and met the needs of their families with few rights and very limited education. Women were virtually absent from the formal practice of public administration (Hunt, 2006).

Public Administration, as a self-aware field, is relatively new. Its origin in the U.S.A. can be traced to Woodrow Wilson (1887) and the call to separate politics and administration. His call was a response to political cronyism, which treated administrative employment as a spoil of political victory. Early male public administration leaders and reformers sought an objective science as an antidote to the excesses and corruption of the spoils system. Public administration of the early twentieth century "was pragmatic, problem-oriented, sustained by faith in progress, efficiency, democratic government, and ... meritocracy" (Mosher, 1975, p. 4). Public administration's male founders explicitly believed in patriarchy as they lived and worked in the public sphere (Stivers, 2002/1993).

With the exception of Mary Parker Follett, the literature that defined this early period was crafted by men. As a contributor to the human relations movement, Follett focused on employee attitudes and behavior as well as executive leadership (Stone and Stone, 1975). Her 1926 essay, "Giving of Orders" represents the lone woman's voice in Shafritz and Hyde's (1978) first edition of the Classics of Public Administration. This innovative work used psychology to show why expectations that employees would follow orders without question were flawed (Follett, 1978/1926).

Women can also claim a public administration origin story. Decades previously, women had slowly begun to craft an alternative approach to public administration. During the 1800 s a few well-educated upper-class women entered the public sphere and performed functions we would call public administration. Florence Nightingale and her efforts to reform military hospitals, develop nursing schools, promote public health through experimental science/sanitation and the women who managed the United States Sanitary Commission during the U.S. Civil War are examples (Shields and Rangarajan, 2011). These pioneers also successfully opened doors of higher education for women often by establishing women's colleges (Giesberg, 2000).

Throughout the history of Western democracies, women and men were strictly demarcated by gender norms. Women, often using the moral authority of motherhood, organized voluntary associations that pushed for reforms and worked outside traditional political structures that barred their participation. By the late 1800s, both in Europe and the United States, 
these associations were networked in a system that spanned the continent. They were led by well-educated, upper-class, white women with the skills and motivation to enter the public sphere (Skocpol, 1992; Hunt, 2006). They saw the excesses of industrialization and urbanization and pushed for reform that served the needs of women and children. Women's civic clubs skillfully organized to reform public spaces, which would enrich and render safer the lives of women and children. They also organized to alter dangerous industrial working spaces. This was a policy arena ignored by their husbands and fathers. Eventually, they organized large effective non-profit organizations (Settlement Houses). These residential, educational/community centers, often situated in urban slums filled with immigrants, organized to make cities more livable and industry safer, and expand the influence of women into the public sphere (Stivers, 2000; Shields, 2017; Burnier, 2008, 2021).

\section{Influence of the Settlement Women}

In the U.S.A., the settlement movement led by women like Jane Addams, Florence Kelley and Julia Lathrop played a key role in developing an alternative model of public administration, which incorporated the actions and ideas of urban women reformers (Stivers, 2000). This alternative model, also known as the settlement model, had two interconnected components, municipal housekeeping and industrial citizenship (McGuire, 2011). Municipal housekeeping focused on the problematic urban environment, where streets were cluttered with infectious garbage, children had no place to play, water brought disease into the home and children were sentenced to adult prisons. This model took as a point of departure that cities should be run like a home that cared for its citizens. Playgrounds, juvenile courts, educational curricular reform, clean streets, and effective sewer and water systems are tangible reforms pushed by settlement women. Industrial citizenship focused on the dangers of the industrial workplace (child labor, unsanitary conditions), affecting products and workers in ways such as physical danger and long hours. Organized settlement women's reform efforts led to workplace safety laws and inspections.

It should be noted that British women of this period also focused their reform efforts on local government, which was the first place they could vote and hold elected office. For example, British women elected to the Education Board taught men that it was unnatural for four-year-olds to sit long hours patiently and silently on hard wooden benches; that children learnt "through play, through exploration, through doing" (Hollis, 1987, p. 187).

Settlement reformers worked with the community as they sought social justice (Burnier, 2021). They acted as a catalyst focusing existing women's social and reform groups on policy changes, which would improve the lives of vulnerable, impoverished families. Both municipal housekeeping and industrial citizenship applied a pragmatic ethic of care informed by feminine experience to policy and administration. Their efforts led to innovative governmental changes. Florence Kelley is a prime example. In 1893 she began her role as chief factory inspector for the State of Illinois. This "gave her an unprecedented opportunity to expand governmental responsibility for social welfare ... Nowhere else in the Western world was a woman trusted to enforce the labor legislation of a city, let alone of a large industrial region the size of Illinois" (Sklar, 1995, p. 237). Ultimately, women's involvement in labor reform and women's issues led to the establishment of the U.S. Women's Bureau and Children's Bureau led by women such as Mary van Kleeck and Julia Lathrop. Kelley's protege, Frances Perkins, became the first woman cabinet member as U.S. Secretary of Labor (1933-45) (Newman, 2004). 


\section{Handbook on gender and public administration}

It should be noted that the settlement movement was composed of what we would now clearly identify as nonprofit organizations that were generally found in urban slums. Here they brought much needed services to the community and helped organize reform of the corrupt, crony capitalism that characterized U.S. state and local government. Their efforts were successful on many fronts. Much of the New Deal legislation included provisions they had worked on for years (unemployment insurance; income for the old, dependent children and disabled; limits on hours worked; and child labor, etc.). Richard Stillman (1998, p. 82) credits Jane Addams and the women of the settlement movement with "conceiving and spawning" the modern welfare state. Although the settlement movement reformers accomplished much, their successes were not noted or evidenced in the literature, or leadership of the newly emerging field of public administration. The alternative or social justice model of public administration was buried or had disappeared (Burnier, 2021).

There are many possible reasons that the contributions of the settlement women never became part of formal PA history. Camilla Stivers (2000) attributes the lost past to the founding men's increasing concern with scientific and efficient administration as well as the role of the executive, which "favored masculine ideas and activities over those thought to be feminine" (p. 14). Reforms like the Council/Manager form of city government allowed cities to be run more like an efficient business, which applied the science of administration. Although perhaps unconscious, this was a gendered framing of public administration that centered on the training of nonpartisan experts who focused on efficient administration and whose "masculinity was unquestionable" (p. 14).

During the progressive era, social work and public administration were less easily distinguishable; both were engaged in reform efforts, but they diverged into two professions, one dominated by men interested in administrative reform, the other by women seeking social policy change (p. 111). The settlement women found a home in social work. The voices of the settlement women were also muted by clear distractions such as two world wars, and the threat of communism, both of which had masculine overtones. Further, the failed experiment with prohibition challenged the utility of women's organizations like the Women's Christian Temperance Union.

We argue that this lost history is a contemporary problem. Today's students of PA should understand that men and women worked to create their field. The men stressed efficiency while the women, who could not vote, worked for reforms that would generate greater equity, diversity and inclusion.

For Western democracies and much of the world, the right to vote is a necessary condition for women's full participation in public life and by extension public administration. It should be noted that while the settlement women advocated municipal housekeeping, they also explicitly embedded within that model a broader more inclusive definition of democracy - one that included the right to vote for women. At that time, women in democracies around the world were busy organizing for suffrage. In 1850, almost no democratic country gave women the right to vote and by 1920, when the U.S.A. granted universal suffrage, many European and Australian women were already voting in local if not national elections (Hunt, 2006). But even with the right to vote, the culture of patriarchy remained and most women had limited control over their family size. So, even though doors of opportunity were beginning to unlock, access to government employment was restricted. Not surprisingly, by the time Americans in public administration organized a professional organization almost no women were at the table. 
We do not know how many members of the LBGTQ+ community worked to reform public administration and policy during the progressive era. At the time, those who did not conform to heteronormative standards of sexual orientation, gender identity, and expression (SOGIE) hid their identity. Mainstream society did not even recognize the notion of transgender and non-binary gender identity. Laws, as well as religious, and social norms, prohibited, suppressed and cursed their very existence. If discovered, they even risked expulsion from their family. As a result, the study of public administration did not include formal discussion of sexual orientation, gender identity and expression.

It should be noted that Hull House provided a communal living space that gave women of all sexual orientations a place to live outside of the scrutiny of patriarchic and religious norms. Further, it is likely that Jane Addams, who had two close women companions over the course of her life, was a lesbian. At that time being a lesbian meant "living marginally, often in secrecy, often shamefully, but always as different, as the 'deviant"' (Penelope, 1986, p. 92). According to Maurice Hamington (2009, p. 66), "for Addams, who emphasized compassionate understanding, her own deviance provided internal resources to empathize with others who were oppressed." This provided her with a perspective that challenged traditional standards and moral codes. Her intersectional identity as a woman and lesbian gave her a vantage point to lead social justice-related reform movements.

\section{The New Profession of Public Administration}

The nascent administrative reform movement initiated by male reformers of the progressive era evolved into a profession with established university courses and a growing literature. Toward the end of Roosevelt's New Deal, the American Society for Public Administration (ASPA) was established (1939). We mark this event as the beginning of PA as an "organized" profession. This important event is used to trace the role of gender in modern PA. Table 1.1 uses the decades between 1939 and 2021 to spotlight key events, people and facts that showcase the role of gender in the professional world of PA. It uses three dimensions (participation in ASPA, scholarship, and U.S. federal policies and employment trends) to do this. The table helps to set the context for the chapters that follow. The ASPA column represents ways women and members of the LGBTQ+ community became involved in professional activities; PA scholarship captures the slow uneven climb of women and people other than cisgendered men in all aspects of scholarship in PA. The U.S. federal government policy and employment trend column identifies a few key events and legislation that influenced gender and PA over the period. It also provides data from the world of practice which mirrors employment trends in PA generally.

Between 1939 and 1960, before the women's movement was established, few women could be found across the three categories. ASPA women held almost no leadership positions. Julia Henderson was the lone woman on ASPA's first National Council. Anna Rosenberg's (Assistant Secretary of Defense) 1951 luncheon address spearheaded women's presence on the ASPA conference stage (Rubin, 1990).

In 1939, when ASPA was founded, the works of Mary Parker Follett represented the lone, recognized contribution by a woman to the scholarly discourse of PA. Lavern Burchfield worked behind the scenes shaping ASPA, the Public Administration Review (PAR) and PA practice. Mary Guy's (2000) PAR article "The Amazing Miss Burchfield” shed light on her early, often invisible, impact on the field. Burchfield received her doctorate in political 


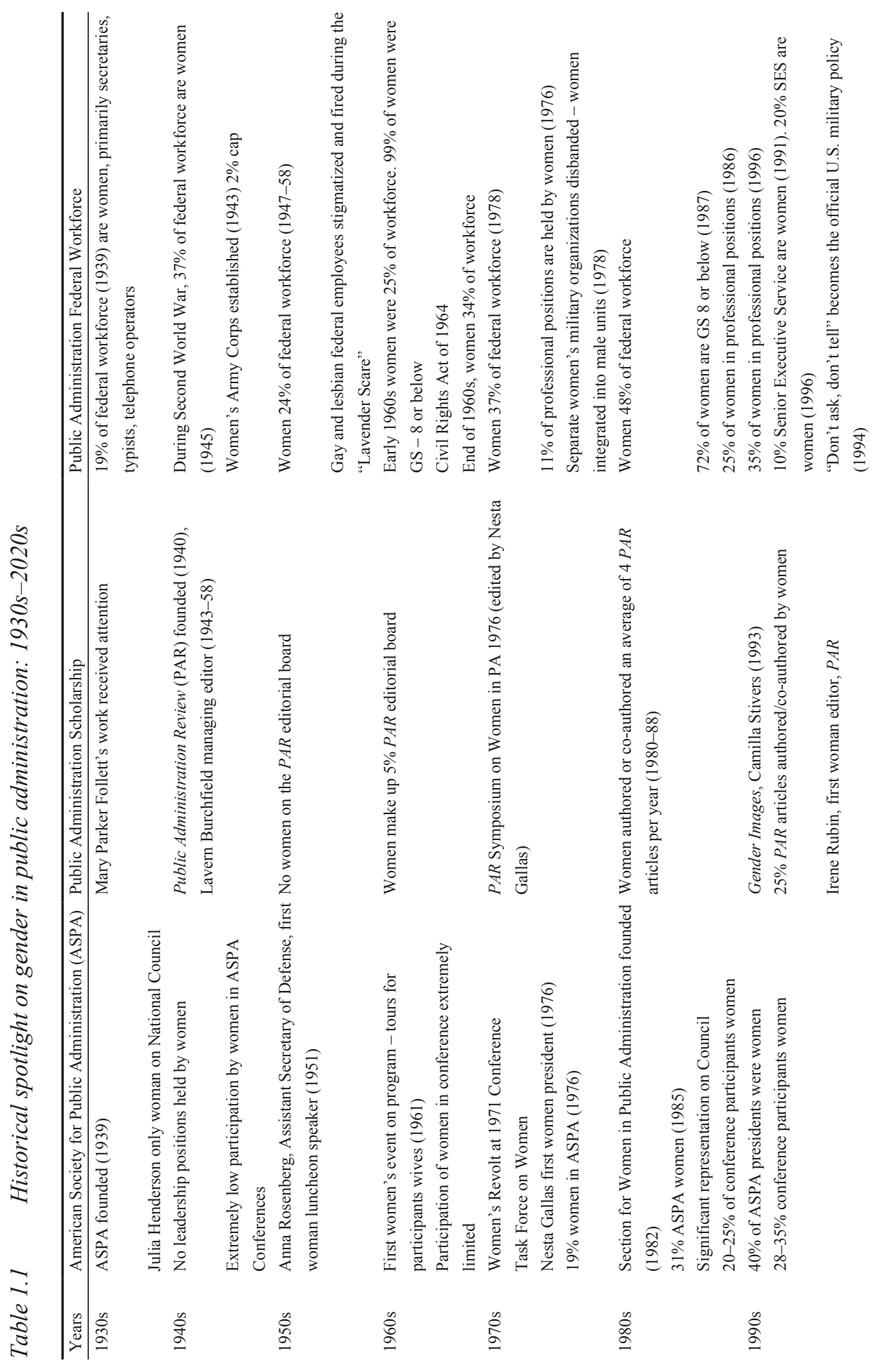


Introduction to the Handbook on Gender and Public Administration 7

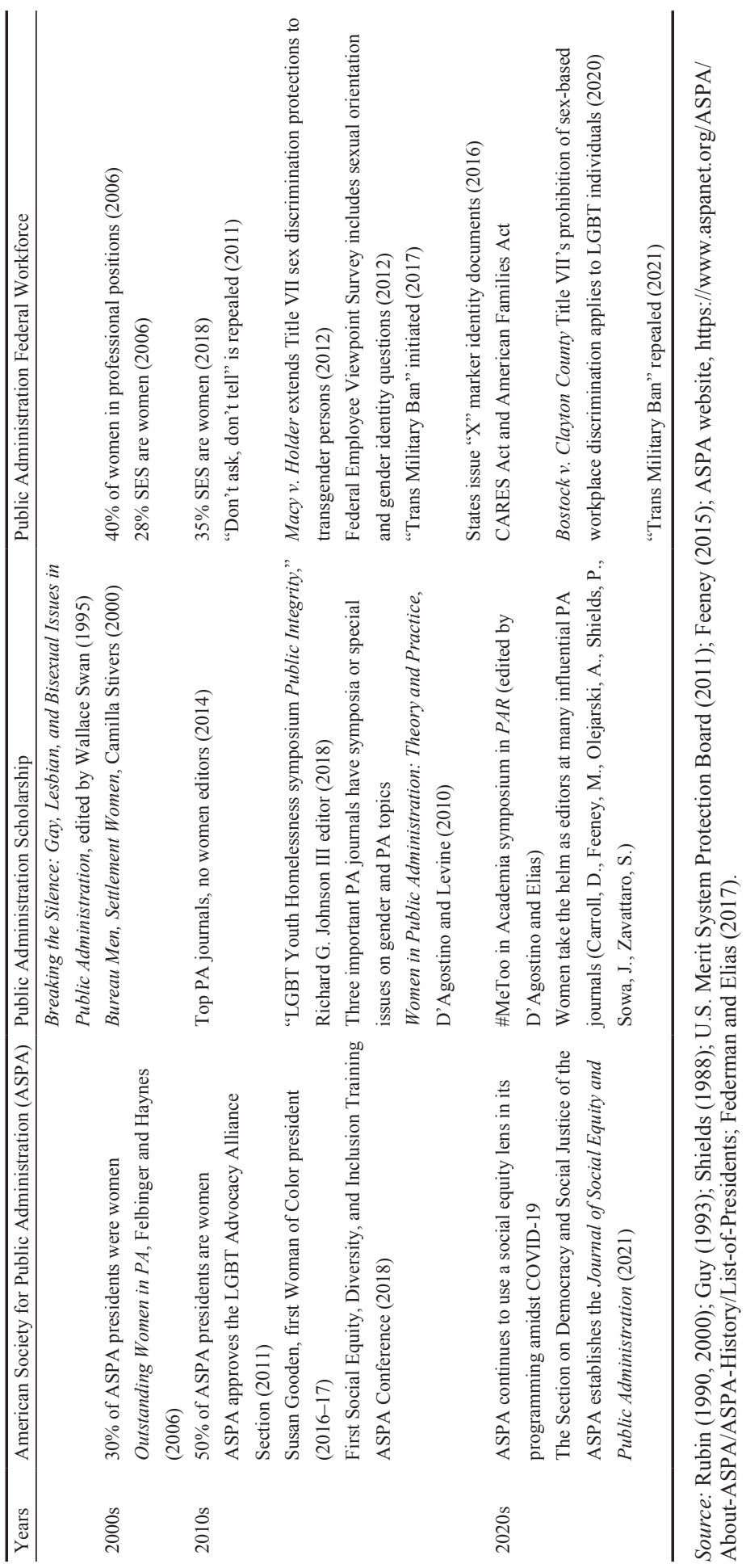


science from the University of Michigan in 1928. Her noted accomplishments included editing influential reports from the Tennessee Valley Authority and the Brownlow Committee. As an ASPA staffer she held the position of Managing Editor for PAR between 1943 and 1958. In this position, she worked closely with authors, sometimes made acceptance decisions and influenced the tone of the journal (Guy, 2000, p. 13).

Women were employed by the federal government making up 19 percent of the workforce in 1939. They were, however, clustered into positions as secretaries, typists and telephone operators (Rubin, 1990). Mirroring employment trends in general, during the war years of the 1940s, women's participation rose to 37 percent of the federal workforce. The Women's Army Corps was established in 1943. This separate, all women's corps gave women the status and benefits of soldiers (Shields, 1988). Women's participation in the military was limited to 2 percent of the force, however. As soldiers returned from the war, women's participation in federal employment fell (24 percent by the 1950s). The times, however, were about to change. Note that for this column, the data presents shifts from overall federal employment to the proportion of women in leadership positions. Women were entering the labor force and federal service in greater numbers, but were facing challenges reaching leadership and decision-making positions. The 1950s was also the height of the Cold War. Under what is called the Lavender Scare, gay and lesbian men and women who worked for government were considered a particular national threat. Their "illegal" behavior put them at risk of blackmail by communist agents. The solution was stigmatization, loss of their government job and possible incarceration (Federman and Elias, 2017; Elias, 2020; McCandless and Elias, 2021).

The 1960s represent a kind of inflection point in U.S. history. The decade saw civil rights protests, an active women's movement, assassinations of a president and civil rights leaders, and the Vietnam War and war protests. It also produced landmark legislation such as the Equal Pay Act of 1963 and the Civil Rights Act of 1964. The culture was also changing. In response to exclusionary and oppressive policy and practices against LGBTQ+ communities, the Stonewall Riots in Greenwich Village in 1969 marked a turning point in sexual orientation, gender identity and expression social movements (McCandless and Elias, 2021). Emerging from Stonewall came gay pride parades, advocacy organizations, and a cultural shift toward greater inclusion, which decades later resulted in more equitable policies for LGBTQ+ individuals in the workplace, public spaces, and identity markers (Elias, 2020; Elias and Colvin, 2020).

Joan Fiss Bishop (1976) credits books like Betty Friedan's (1963) Femine Mystique, the establishment of women's rights organizations like the National Organization for Women (1966) and the Women's Equity Action League (1968) as pushing the question of women and minority rights to a broader public agenda. Federal employment statistics reflect these changes. The percentage of women in federal employment grew from 25 percent to 34 percent over the decade. However, women were still clustered in the lower paying job sectors.

The civil unrest of the 1960s was manifest in the public administration profession through the new public administration movement. "Under the stimulating patronage of Dwight Waldo, some of the best of the younger generation of scholars challenged the doctrine they had received" (Schick, 1975, p. 161). These new scholars wanted a more policy-oriented PA that responded to the turbulent times. The new public administration literature that emerged from Minnowbrook "stressed four themes: relevance, values, equity and change" (p. 162). All of these themes would encourage more participation among women. Ironically, the themes 
echoed the buried work of the settlement women and the alternative vision of public administration described earlier.

The1970s brought significant change for ASPA. In the early 1970s, racial and ethnicity minority members and women members organized to seek greater participation in ASPA (Foye-Cox, 2006). The leaders of the movement wanted to remove the "invisibility" of women from public administration practice, research and scholarship. Marilyn Rubin (1990, p. 286) characterized the nature of the change as a "revolt". A Task Force on Women was established during the 1971 ASPA conference (p. 278). The next year, topics such as "The Liberation of Women in Public Administration" could be found at the conference (Foye-Cox, 2006, p. 24).

By 1976, Nesta Gallas became the first woman president of ASPA and women's participation in ASPA reached 19 percent. In addition, the PAR included a Symposium on Women in PA, edited by Nesta Gallas. The symposium focused on reasons for "discrimination against, underrepresentation of and underutilization of women in public administration" (Gallas, 1976, p. 347). She also noted that "Lurking throughout each of these articles is the specter of sexism in traditional strongholds, everywhere, at high levels and in processes designed to combat it" (p. 348). It is worth noting that a second symposium on this topic, "The Future of Women in Public Administration" did not appear in Administration \& Society until 2017, over 40 years after Gallas's first symposium (D'Agostino and Elias, 2017).

By 1978, women made up 37 percent of the federal workforce. They also occupied 11 percent of professional positions (1976). Throughout this time and into the early 1980s women began to serve as cabinet secretaries in greater numbers. Examples include Carla Hills (Housing and Urban Development), Juanita Kreps (Commerce) and Patricia Roberts Harris (Housing and Urban Development) (Foye-Cox, 2006, pp. 15-17).

The end of the Vietnam War and the creation of the All-Volunteer Force led to a military manpower shortage. In response to the shortage, women's separate organizations such as the Women's Army Corps were disbanded and the 2 percent cap on enlistment scrapped. Women served alongside men in units although they were restricted from combat and many other occupational specialties (Shields, 1988).

In 1975, Luther Gulick wrote a prescient article about the future of Public Administration. This founder of the American Society of Public Administration began his career in the New York Bureau of Municipal Research. In this article, he noted the fundamental changes to American society ushered in by the New Deal and lamented that "public administration as a branch of knowledge and study and even more as an educational field, has been slow indeed to adjust to the significance of this revolutionary shift in American history" (Gulick, 1975, p. 264). The 82-year-old Gulick included a gender dimension as he speculated about changes in how the notion of "MAN" in public administration had changed. He saw a "NEW MAN (and WOMAN)" who was "more complex, more unpredictable, more worthwhile, more creative ... more motivated by ... love, more exciting, lovable and real than any of the older shadows" (p. 266). He then went on to call on public administration to change the way it dealt with "this man/woman/child" in its thinking and work (p. 266).

During the 1980s, women continued to make significant progress along all three dimensions. The earlier Task Force on Women became the active and influential Section for Women in Public Administration (SWPA) (1982). SWPA facilitated networking and was an incubator of future ASPA leaders. Women's participation in ASPA grew to 31 percent, their presence on Council grew and women composed 20-25 percent of ASPA conference panels. Women were adding to scholarly works by contributing, on average, four $P A R$ articles per year (Rubin, 
1990). Women now made up almost half of the federal workforce and increased their presence in professional positions (25 percent). Through the AIDS epidemic beginning in the 1980s, the public paid greater attention to LGBTQ+ issues, particularly the inequities members of these communities faced in social, political, health and economic contexts. Yet, despite this growing visibility, little progress was made in the context of ASPA and the profession of public administration.

During the 1990s, women's influence along all dimensions of public administration and the profession grew. Forty percent of ASPA presidents and one third of ASPA panel members were women; women filled the ranks of the federal workforce. Attention now shifted to the proportion of women at the top. At the beginning of the decade, 10 percent of the Senior Executive Service (SES) were women; by 1996 this had grown to 20 percent. This was also the decade when the military officially softened its ban on gays and lesbians serving in the U.S. military. The "Don't ask, don't tell" policy made it illegal for gay and lesbian service members to disclose their identity. Thus, under this unpopular policy, as long as it was a secret, it was okay to serve in the military and be gay.

Irene Rubin became the first woman editor of $P A R$ during the 1990s and women's contributions to $P A R$ grew to 25 percent. Camilla Stivers published the influential Gender Images in Public Administration in 1993, the first book to apply the lenses of gender to PA. Wallace Swan's (1995) edited Breaking the Silence: Gay, Lesbian, and Bisexual Issues in Public Administration was the first PA book to discuss LGTQ+ issues.

In 2000, Camilla Stivers published Bureau Men, Settlement Women: Constructing Public Administration in the Progressive Era. This landmark book introduced the field to the settlement women's vision of public administration. It set the stage for extensive scholarship in the history of women in public administration. The Section for Women in Public Administration was also trying to document the current and historical role of women in PA. In 2006, with the support of SWPA, Wendy Haynes and Clair Felbinger (2006a, 2006b) put together two edited volumes. One included full-length articles of historical figures and the other vignettes of contemporary scholars and practitioners - the books were published by ASPA. Although certainly far from parity, the proportion of women in the Senior Executive Service had risen to 28 percent.

In the 2010s, women in ASPA had achieved near parity with men. For example, half of ASPA presidents during that time were women. The first woman of color, Susan Gooden, was ASPA president from 2016 to 2017 . Women filled the ranks of university professors in PA programs and were authoring and co-authoring articles in the leading journals. LGBTQ+ recognition continued to grow and the ASPA National Council approved the LGBT Advocacy Alliance Section in 2011, which has continued to grow in membership and stature.

Attention in scholarship turned to the role of women as journal editors. Mary Feeney (2015) illustrated this with a 2015 picture of an ASPA panel of PA editors. The eight white men in the picture demonstrated the dearth of women and minorities in these positions. In addition, scholars started looking at PA syllabi and found that most assigned readings were written by men (Hatch, 2018). Women continued to make gains in federal leadership positions (35 percent of SES were women in 2018). Three PA journals, Administration \& Society, Public Integrity and Administrative Theory and Praxis, had symposia or special issues on gender and PA-related topics. D'Agostino and Elias (2017) edited the second symposium on women in the field, "The Future of Women in Public Administration" in Administration \& Society. The First LGBT Symposium appeared in Public Integrity "LGBT Youth Homelessness" (2018) and 
was edited by Richard Gregory Johnson III (2018). Administrative Theory \& Praxis published a "Special Issue on Gender Identity and Expression and Sexual Orientation (LGBTQ+) in the Public and Nonprofit Contexts" edited by Roddrick Colvin (2020). With growing recognition of sexual harassment and assault in academia, the "\#MeToo in Academia: Understanding and Addressing Pervasive Challenges" Viewpoint Symposium was published in PAR (D'Agostino and Elias, 2020).

The 2010s through the early 2020s was a period of significant change for sexual orientation and gender identity issues in federal employment. In the military, policy for LGBTQ+ service members fluctuated from administration to administration. "Don't ask, don't tell" was repealed in 2011, but then the Trump administration instituted a "Trans Military Ban" in 2017. Generally, there was a progression toward greater LGBTQ+ visibility and equity. The Federal Employee Viewpoint Survey began including sexual orientation and gender identity questions for the first time in 2012. The landmark case Macy v. Holder was issued in 2012, holding that discrimination against someone because he or she is transgender, falls under Title VII's "sex discrimination." Most recently, gender norms and definitions have become more fluid with non-binary and transgender identities gaining recognition and rights (Elias, 2017, 2020, 2022). In 2016, states began issuing " $\mathrm{X}$ " marker identity documents in the form of birth certificates and driver's licenses (Elias and Colvin, 2020; Elias, 2022), and the Biden administration recently voiced support for the "X" marker to represent gender identity beyond "male" and "female" on federal identity documents.

In 2020, the onset of the COVID-19 pandemic disrupted much of "normal" life for academics and practitioners alike. ASPA continued to apply a social equity lens in its programming amidst COVID-19. In 2021, ASPA's Section on Democracy and Social Justice of the ASPA established the Journal of Social Equity and Public Administration. New legislation for federal workers in response to COVID-19 and child care included a focus on equity with the Cares Act and the American Families Plan. During this time period, LGBTQ+ rights continued to expand in case law and policy. In 2020, the landmark ruling Bostock v. Clayton County held that Title VII's prohibition of sex-based discrimination applies to LGBT individuals in the workplace (McCandless and Elias, 2021).

\section{ORGANIZATION OF THE HANDBOOK ON GENDER AND PUBLIC ADMINISTRATION}

This Handbook is divided into three Parts. Part I covers the history and theories associated with gender and public administration; Part II focuses on how "pillars" or core concepts of public administration intersect with gender; Part III explores the context of gender in public administration. This somewhat eclectic section examines gender in the context of policy, the gendered environment, state and local government, PA scholarship, PA faculty experience, and international cases.

\section{Part I: Theoretical and Historical Roots}

The theoretical and historical underpinnings of gender and PA are intertwined because as women began to leave the private sphere of the home and move into a public sphere they drew on their feminine experience to reform public policy and theorize about public administration. 
Throughout this history, driven by social equity concerns, women have pushed for greater rights, responsibility and influence. Their journey sets the context for the way gender and public administration interact in contemporary settings.

The formal study of gender and public administration began with Camilla Stivers's (2002/1993) book Gender Images in Public Administration. This influential book blended history and feminist theories to show how masculine images dominate public administration heritage, theory and practice. In Chapter 2, Jennifer Alexander and María Verónica Elías (2022) explore the influence of Gender Images and Stivers's thought on public administration over three decades. In Chapter 3, Patricia Shields (2022) takes an historical journey that explores the stories of early women pioneers in public administration. DeLysa Burnier (2022) continues the historical analysis in Chapter 4 by reinserting care, gender and social justice into the historical narrative around the Progressive and New Deal Eras. She uses the lens of care ethics to examine approaches to leadership and administration developed by Jane Addams and Frances Perkins.

Women have historically engaged in labor like care for a sick family member which explicitly drew on emotional resources. Teaching, nursing and social work are fields that require high degrees of emotional labor and that are dominated by women. In Chapter 5, Ganapati, Remington and Newman (2022) explore the theory, practice and scholarship of emotional labor and tie it to gender and public administration.

Up until this point, the focus of the Handbook has been on women in PA. Chapter 6 by Nuri Heckler (2022), "Managing Masculinity in Public Organizations," enhances the scope of our analysis. He argues that scholars in PA should consciously study hegemonic masculinity in order to gain a more complete understanding of how gender shapes public organizations. In "Beyond Binary" (Chapter 7) Nicole Elias (2022) examines new policy areas that strengthen the rights of LBGTQ+ people who identify as non-binary: first, internal public workplace policies that address transitioning in an employment context and second, public policy that offers a third gender option, represented by an "X," on government-issued identity documents. In Chapter 8, Schnequa Nicole Diggs (2022) uses the concept of intersectionality to show how intersecting identities of gender and race create unique inequalities that limit access to government.

\section{Part II: Pillars of Public Administration}

Part II of the Handbook examines traditional core areas of public administration and looks at them through the lenses of gender. These include topics like budgeting, human resources, ethics and bureaucracy - subjects found in MPA Program core courses.

In Chapter 9, Marilyn Rubin and John Bartle (2022) examine international efforts to use budgets to advance gender equity. They highlight the many successes of gender-responsive budgeting among more than 80 countries that have implemented these budgetary systems at national and sub-national levels. Public personnel managers play an instrumental role in implementing programs that influence gender parity in the public workplace. In Chapter 10, Nandhini Rangarajan and Mark Lottman (2022) use a global perspective to analyze how contemporary public administration human resource scholarship treats gender. In Chapter 11, Jennifer Fenton (2022) discusses the overwhelming influence of ethical theories authored by men, rooted in classical liberalism in PA ethics courses. She offers Jane Addams's feminist pragmatist framework of democracy as social ethics as a way to better incorporate social 
equity into PA ethics. Public organizations perform the work of public administration. In Chapter 12, Sebawit Bishu (2022a) examines the social norms and stereotypes that influence experiences of women who work in public organizations. She finds an environment that is evolving from an exclusive masculine domain, yet has a long way to go to reach gender parity.

Nonprofit administration began to appear in the PA curriculum in the 1970s. It is now well respected as an essential component in most MPA Programs. In Chapter 13, Michelle Evans and Hillary Knepper (2022) examine the past, present and future role of gender in the nonprofit administration. In Chapter 14, Jennifer Hooker and Mary Guy (2022) consider representative bureaucracy theory as a way to deal with the problems gender brings to governance. They explore gender as a continuum well beyond the binary conceptualization. As something of a bonus, this chapter provides a useful table filled with definitions of key gender-related terms. Performance measurement is an important tool used by public administrators to track efficiency, economy and effectiveness. In Chapter 15, Samantha Larson (2022) considers performance measurement in light of gender equity. Using four types of equity indicators access, quality, procedural fairness and outcomes - she shows how performance measurement can support gender equity objectives. The study of public service motivation has become one of the most studied facets of contemporary public administration. In Chapter 16, Nicole Humphrey (2022) examines the neglected nexus of gender and public service motivation.

\section{Part III: Contexts of Gender and Public Administration}

Part III of the Handbook shows ways the dynamic contexts of PA intersect with gender. We tried to make this section something like a coherent set of snapshots that summarizes a dynamic event. The snapshots can never do justice to the event, but can also communicate something of the breadth, depth and multiple points of view.

The field of public administration has made many strides since the early twentieth century, making the field more equitable and welcoming to women and the LGBTQ+ community. In Chapter 17, Helisse Levine, Maria D'Agostino and Meghna Sabharwal (2022) show how gender bias in the PA workplace has changed as they examine second-generation gender bias. The \#MeToo movement emerged as a way for women to share experiences about sexual assault and harassment. In addition, it has been a catalyst for organized protest and policy change. In Chapter 18, Sean McCandless (2022) investigates how workplace legal requirements have changed at the federal and state level in response to the \#MeToo movement.

In Chapter 19, Sharon Mastracci and Nadia Mahallati (2022) look at changes of upper-level women state administrators' experiences over a 30-year time period. They replicate a 1986 study of Utah women administrators with a 2016 survey and found women's salaries were still significantly below their male counterparts. In addition, contemporary women administrators were more likely to be married with small children. We shift to local government in Chapter 20. Here Ashley Wayman, Samantha Alexander and Patricia Shields (2022) consider women's path to the city manager position using resume data from Texas City Managers and survey data from women in the city manager pipeline. They recommend greater attention to mentoring programs for women in the city management profession as a way to increase the proportion of women city managers.

Public administration operates within a larger policy context. The next three chapters capture gender dimensions in housing, agricultural and military policy. Although the U.S.A. outlawed gender discrimination in housing in 1974, Megan Hatch (2022) shows, in Chapter 
21 , how seemingly gender-neutral programs have design flaws that result in gender discrimination through disparate impact. In Chapter 22, Aritree Samanta, Shilpa Viswanath and Mary Anh Quyen Tran (2022) consider the multiple representation challenges women face as they deal with natural resource conservation agencies. The historical masculine and gendered nature of the agricultural sector creates challenges for women farmers and women who work in agencies such as the Natural Resources Conservation Service and the Farm Service Agency. Only since the 1970s have Western militaries begun to open up permanent active service to women. In Chapter 23, Lindy Heinecken (2022) recounts the uneven progress of women's integration into militaries across the world.

In Chapter 24, Zoë Klobus, Michelle Evans and Hillary Knepper (2022) examine the gendered dimensions of PA scholarship. This expansive chapter considers what is being written, who is producing the scholarship and how it is influencing contemporary public administration. Women fill graduate PA classes yet they are less likely than their male counterparts to reach the rank of full professor or to fill a leadership position in their institutions. In Chapter 25, Beth Rauhaus and Isla Schuchs Carr (2022) examine reasons why women leak from the academic ranks.

Melissa Gómez Hernández (2022) examines the role of gender in the 2016 Colombian peace agreement in Chapter 26, which recounts the story of a peace agreement which initially used an expansive notion of gender that incorporated the rights and voices of women and the LGBTQ+ community. A subsequent backlash diluted the original agreement, placing emphasis on order and conservative visions of gender. The Handbook ends with an amazing success story - Ethiopia's National Policy on Women. Sebawit Bishu (2022b) tells the story of Ethiopia's commitment to gender equality reform that began in 1993 in Chapter 27. These policies paid particular attention to leadership and by 2019 Ethiopia had its first woman president and the first female head of the highest court; in addition, 38 percent of parliament and half of the cabinet seats were held by women.

\section{CONCLUDING THOUGHTS AND FUTURE AVENUES}

This volume provides a starting point to better understand and promote gender equity in theory and practice. Our hope is that this Handbook provides a basis for seeing and understanding gender in new ways that can inform future theory and practice.

COVID-19, as a focusing event, is a means to see gender, especially the gendered aspects of care and labor. In 2021, there is a growing understanding that gender, along with other demographic identities, shapes one's experience with public administration and policy. COVID-19 shined light on several gendered dimensions of public administration and policy that have significant social, political and economic consequences. The pandemic gripped the world in March 2020, brought a plethora of disparities and inequities to the surface in the current U.S. context, prompting us to question our most fundamental structures and practices, particularly along gender lines (Elias and D'Agostino, 2020). The relationship between women's (especially mothers') careers, and child care in the U.S.A. was of prime concern for policymakers and administrators. Child care inequities were persistent in the United States, dating back to the end of the Second World War (Pynes and Rissler, 2017). Gender inequities regarding child care are especially troubling, because they perpetuate additional disparities along health, income and race lines. 
The gender dimensions and dependency of the U.S. economic system on weak and costly child care are evident. Data show that women, especially women of color, were disproportionately affected by the closing of schools as they carry out most of the duties involving child care and that women are more likely to leave the workforce when affordable child care is unavailable (Elias and D'Agostino, 2020). Women of color experienced job loss at a disproportionate rate relative to all women and the general population (Connley, 2021). As of December 2020, Hispanic women and African American women experienced unemployment rates of 9.1 percent and 8.4 percent, respectively (Connley, 2021). This compared unfavorably with 5.7 percent and 5.8 percent of white women and white men, respectively (Connley, 2021). The paradox of this crisis was that women were either losing their jobs, had to choose between work and caregiving, or were out on the frontlines as essential workers.

The pandemic accentuated the challenges women face, particularly the dual burden as the primary caregiver and breadwinner for women, especially women of color. Women represent 55 percent of the 20.5 million jobs lost since April 2020. In December 2020, 156,000 women lost jobs compared to 16,000 jobs added for men (Connley, 2021). Women represent 55 percent of the 9.8 million net jobs lost from April 2020 to December 2020 (Connley, 2021). In response to these alarming caregiving and paid labor gender disparities during COVID-19, Reshma Saujani, Founder and CEO of Girls Who Code, developed the "Marshall Plan for Moms." The Marshall Plan gained international attention when Girls Who Code ran a full-page ad in The New York Times on January 26, 2021 as a letter addressed to newly elected President Biden. Similar to the original Marshall Plan of 1948, the 2021 plan would be financial investment in gender equity in the paid labor market. The Marshall Plan for Moms aims to accomplish the following: establish a task force to create a formal Marshall Plan for Moms; implement a short-term monthly payment to moms depending on needs and resources; and pass long overdue policies like paid family leave, affordable child care and pay equity (https://www.marshallplanformoms.com).

Beyond the immediacy of COVID-19, public administration policy should not only account for women who are disproportionately harmed by the short- and long-term consequences of this focusing event, but also should seriously examine gendered dimensions of administration and policy. Chapters in this book serve as the most comprehensive discussion of gender in public administration. As such a reference, this is not the end of the gender story in our field. This is a way to begin to explore gender in public administration in greater detail and new ways in the twenty-first century.

\section{REFERENCES}

Alexander, J. and Elías, M. (2022). Revisiting Camilla Stivers's Gender Images in Public Administration. In Shields, P. and Elias, N. (Eds.), Handbook on Gender and Public Administration. Cheltenham, UK and Northampton, MA, USA, Edward Elgar Publishing.

Bishop, J.F. (1976). The women's movement in ASPA. Public Administration Review, 36(4), 349-54.

Bishu, S. (2022a). Women's representation in public sector organizations: persistent challenges and potential for change. In Shields, P. and Elias, N. (Eds.), Handbook on Gender and Public Administration. Cheltenham, UK and Northampton, MA, USA, Edward Elgar Publishing.

Bishu, S. (2022b). Governing for equity: the Ethopian case. In Shields, P. and Elias, N. (Eds.), Handbook on Gender and Public Administration. Cheltenham, UK and Northampton, MA, USA, Edward Elgar Publishing. 
Burnier, D. (2008). Erased history: Frances Perkins and the emergence of care-centered public administration. Administration \& Society, 40(4), 403-22.

Burnier, D. (2021). Hiding in plain sight: recovering public administration's lost legacy of social justice, Administrative Theory \& Praxis, https://doi.org/10.1080/10841806.2021.1891796.

Burnier, D. (2022). The long road of administrative memory: Jane Addams, Frances Perkins and care-centered administration. In Shields, P. and Elias, N. (Eds.), Handbook on Gender and Public Administration. Cheltenham, UK and Northampton, MA, USA, Edward Elgar Publishing.

Colvin, R. (Ed.) (2020). Special Issue on Gender Identity and Expression and Sexual Orientation (LGBTQ+) in the Public and Nonprofit Contexts. Administrative Theory \& Praxis, 42(2), 111-14.

Connley, C. (2021). A year ago, women outnumbered men in the U.S. workforce, now they account for $100 \%$ of jobs lost in December. January 11, CNBC. https://www.cnbc.com/2021/01/11/women -account-for-100percent-of-jobs-lost-in-december-new-analysis.html.

D'Agostino, M.J. and Elias, N.M. (Eds.) (2017). The future of women in public administration. Administration \& Society, 49(1), 4-8. https://doi.org/10.1177/0095399716685794.

D’Agostino, M.J. and Elias, N.M. (Eds.) (2020). \#MeToo in academia: understanding and addressing pervasive challenges. Viewpoint Symposium in Public Administration Review. https://doi.org/10 .1111 puar.13318.

D'Agostino, M.J. and Levine, H. (2010). Women in Public Administration: Theory and Practice. Jones \& Bartlett Publishers.

Diggs, S.N. (2022). Intersectionality of gender and race in governmental affairs. In Shields, P. and Elias, N. (Eds.), Handbook on Gender and Public Administration. Cheltenham, UK and Northampton, MA, USA, Edward Elgar Publishing.

Elias, N.M. (2017). Constructing and implementing transgender policy for public administration. Administration \& Society, 49(1), 20-47. https://doi.org/10.1177/0095399716684888.

Elias, N.M. (2020). LGBTQ+ civil rights: local government efforts in a volatile era. Public Administration Review. https://doi-org.ez.lib.jjay.cuny.edu/10.1111/puar.13188.

Elias, N.M. (2022). Beyond binary treatment of gender in public administration and policy. In Shields, P. and Elias, N. (Eds.), Handbook on Gender and Public Administration. Cheltenham, UK and Northampton, MA, USA, Edward Elgar Publishing.

Elias, N.M. and Colvin, R. (2020). A third option: understanding and assessing non-binary gender policies in the United States. Administrative Theory \& Praxis, 42(2), 191-211. https://doi.org/10.1080/ 10841806.2019.1659046.

Elias, N.M. and D'Agostino, M.J. (2020). Care in crisis: COVID-19 as a catalyst for universal child care in the United States. Administrative Theory \& Praxis. https://doi.org/10.1080/10841806.2020 .1813456 .

Evans, M. and Knepper, H. (2022). Gender and nonprofit administration: past, present and future. In Shields, P. and Elias, N. (Eds.), Handbook on Gender and Public Administration. Cheltenham, UK and Northampton, MA, USA, Edward Elgar Publishing.

Federman, P.S. and Elias, N.M. Rishel (2017). Beyond the Lavender Scare: LGBT and heterosexual employees in the federal workplace. Public Integrity, 19(1), 22-40. https://doi.org/10.1080/10999922 .2016.1200410.

Feeney, M.K. (2015). Power in editorial positions: where are the women in public administration? Available at SSRN 2611771.

Fenton, J.K. (2022). Gender in administrative ethics: Jane Addams's feminist pragmatist conception of democracy as social ethics. In Shields, P. and Elias, N. (Eds.), Handbook on Gender and Public Administration. Cheltenham, UK and Northampton, MA, USA, Edward Elgar Publishing.

Follett, M.P. (1978/1926). The giving of orders. In Shafritz, F. and Hyde, A. (Eds.), Classics of Public Administration, pp. 29-37. Moore Publishing Co.

Foye-Cox, N. (2006). Women in public administration: breaking new ground. In Felbinger, C. and Haynes, W. (Eds.), Profiles of Outstanding Women in Public Administration, pp. 7-42. American Society for Public Administration.

Friedan, B. (1963). The Feminine Mystique. W.W. Norton.

Gallas, N. (1976). Introductory comments. Public Administration Review, 36(4), 347-9. 
Ganapati, N.E., Remington, C. and Newman, M. (2022). Emotional labor, gender and public administration. In Shields, P. and Elias, N. (Eds.), Handbook on Gender and Public Administration. Cheltenham, UK and Northampton, MA, USA, Edward Elgar Publishing.

Giesberg, J.A. (2000). Civil War Sisterhood: The U.S. Sanitary Commission and Women's Politics in Transition. Northeastern University Press.

Gómez Hernández, M. (2022). Gender and the construction of a positive peace within the 2016 Colombian peace deal. In Shields, P. and Elias, N. (Eds.), Handbook on Gender and Public Administration. Cheltenham, UK and Northampton, MA, USA, Edward Elgar Publishing.

Gulick, L. (1975). George Maxwell has a dream: a historical note with a comment on the future. In Mosher, F. (Ed.), American Public Administration: Past, Present, Future, pp. 253-67. University of Alabama Press.

Guy, M.E. (1993). Three steps forward, two steps backward: the status of women's integration into public management. Public Administration Review, 53(4), 285-92.

Guy, M.E. (2000). The amazing Miss Burchfield. Public Administration Review, 60(1), 6-19.

Hamington, M. (2009). The Social Philosophy of Jane Addams. University of Illinois Press.

Hatch, M.E. (2018). Quiet voices: misalignment of the three Cs in public administration curriculum. Journal of Public Affairs Education, 24(2), 152-72.

Hatch, M.E. (2022). When gender-neutral rental housing policy becomes gender-inequitable. In Shields, P. and Elias, N. (Eds.), Handbook on Gender and Public Administration. Cheltenham, UK and Northampton, MA, USA, Edward Elgar Publishing.

Haynes, W. and Felbinger, C. (Eds.) (2006a). Profiles of Outstanding Women in Public Administration. American Society for Public Administration.

Haynes, W. and Felbinger, C. (Eds.) (2006b). Outstanding Women in Public Administration. American Society for Public Administration.

Heckler, N. (2022). Managing masculinity in public organizations. In Shields, P. and Elias, N. (Eds.), Handbook on Gender and Public Administration. Cheltenham, UK and Northampton, MA, USA, Edward Elgar Publishing.

Heinecken, L. (2022). Women and military service. In Shields, P. and Elias, N. (Eds.), Handbook on Gender and Public Administration. Cheltenham, UK and Northampton, MA, USA, Edward Elgar Publishing.

Hollis, P. (1987). Ladies Elect: Women in English Local Government, 1865-1914. Oxford University Press.

Hooker, J. and Guy, M.E. (2022). Gender and representative bureaucracy. In Shields, P. and Elias, N. (Eds.), Handbook on Gender and Public Administration. Cheltenham, UK and Northampton, MA, USA, Edward Elgar Publishing.

Humphrey, N. (2022). Gender and public service motivation: recognizing gender as a social structure. In Shields, P. and Elias, N. (Eds.), Handbook on Gender and Public Administration. Cheltenham, UK and Northampton, MA, USA, Edward Elgar Publishing.

Hunt, K. (2006). Women as citizens: changing the polity. In Simonton, D. (Ed.), The Routledge History of Women in Europe Since 1700, pp. 216-58. Routledge.

Johnson III, R.G. (2018). Public administration's ethical dilemma: homeless LGBT youth in the twenty-first century. Public Integrity, 20(6), 539-41.

Klobus, Z., Evans, M. and Knepper, H. (2022). Gender and public administration scholarship. In Shields, P. and Elias, N. (Eds.), Handbook on Gender and Public Administration. Cheltenham, UK and Northampton, MA, USA, Edward Elgar Publishing.

Larson, S. (2022). Performance, social equity, and gender. In Shields, P. and Elias, N. (Eds.), Handbook on Gender and Public Administration. Cheltenham, UK and Northampton, MA, USA, Edward Elgar Publishing.

Levine, H., D'Agostino, M. and Sabharwal, M. (2022). Making the case for addressing second-generation gender bias in public administration. In Shields, P. and Elias, N. (Eds.), Handbook on Gender and Public Administration. Cheltenham, UK and Northampton, MA, USA, Edward Elgar Publishing.

Mastracci, S. and Mahallati, N. (2022). "Backwards in high heels": revisiting gender in Utah state government and administration after 30 years. In Shields, P. and Elias, N. (Eds.), Handbook on Gender and Public Administration. Cheltenham, UK and Northampton, MA, USA, Edward Elgar Publishing. 
McCandless, S. (2022). \#MeToo and human resources legislation: history, legal patterns, and prospects. In Shields, P. and Elias, N. (Eds.), Handbook on Gender and Public Administration. Cheltenham, UK and Northampton, MA, USA, Edward Elgar Publishing.

McCandless, S. and Elias, N.M. (2021). Beyond Bostock: implications for LGBTQ+ theory and practice. Invited Essay. Administrative Theory \& Praxis. https://doi.org/10.1080/10841806.2020.1840903.

McGuire, J.T. (2011). Continuing an alternative view of public administration: Mary van Kleeck and industrial citizenship, 1918-1927. Administration \& Society, 43(1), 66-86.

Mosher, F. (1975). Introduction: the American setting. In Mosher, F. (Ed.), American Public Administration: Past, Present, Future, pp. 1-10. University of Alabama Press.

Newman, M.A. (2004). Madam Secretary: Frances Perkins. In Felbinger, C. and Hanes, W. (Eds.), Outstanding Women in Public Administration: Leaders, Mentors, and Pioneers, pp. 83-102. Routledge.

Penelope, J. (1986). The lesbian perspective. In Allen, J. (Ed.), Lesbian Philosophies and Cultures, pp. 88-108. State University of New York Press.

Pynes, J.E. and Rissler, G.E. (2017). Social equity in the Trump era: what can local public administrators do to improve social equity for their residents and community in the face of federal cuts? State and Local Government Review, 49(1), 48-59.

Rangarajan, N. and Lottman, M. (2022). Trends in international scholarship on gender and public personnel administration (2008-19). In Shields, P. and Elias, N. (Eds.), Handbook on Gender and Public Administration. Cheltenham, UK and Northampton, MA, USA, Edward Elgar Publishing.

Rauhaus, B. and Schuchs Carr, I. (2022). The leaky pipeline: gender and public administration professional education. In Shields, P. and Elias, N. (Eds.), Handbook on Gender and Public Administration. Cheltenham, UK and Northampton, MA, USA, Edward Elgar Publishing.

Rubin, M. (1990). Women in ASPA: the fifty-year climb toward equality. Public Administration Review, $50(2), 277-87$.

Rubin, M. (2000). Women in the American Society for Public Administration: another decade of progress but still a way to go. Public Administration Review, 60(1), 61-71.

Rubin, M. and Bartle, J. (2022). Gender-responsive budgeting: a global perspective. In Shields, P. and Elias, N. (Eds.), Handbook on Gender and Public Administration. Cheltenham, UK and Northampton, MA, USA, Edward Elgar Publishing.

Samanta, A., Viswanath, S. and Tran, M.A.Q. (2022). It is very much a man's world: gender representation in agricultural policy and administration. In Shields, P. and Elias, N. (Eds.), Handbook on Gender and Public Administration. Cheltenham, UK and Northampton, MA, USA, Edward Elgar Publishing.

Schick, A. (1975). The trauma of politics: public administration in the sixties. In Mosher, F. (Ed.), American Public Administration: Past, Present, Future, pp. 142-80. University of Alabama Press.

Shafritz, J.M. and Hyde, A.C. (1978). Classics of Public Administration. Moore Publishing Co.

Shields, P. (1988). Sex roles in the military. In Moskos. C. and Wood, F.R. (Eds.), The Military: More than just a Job, pp. 99-113. Pergamon-Brassey.

Shields, P. (2017). Jane Addams: pioneer in american sociology, social work and public administration. In Shields, P. (Ed.), Jane Addams: Progressive Pioneer of Peace, Philosophy, Sociology, Social Work and Public Administration, pp. 43-67. Springer.

Shields, P. (2022). The origins of the settlement model of public administration. In Shields, P. and Elias, N. (Eds.), Handbook on Gender and Public Administration. Cheltenham, UK and Northampton, MA, USA, Edward Elgar Publishing.

Shields, P. and Rangarajan, N. (2011). Public service professionals: the legacy of Florence Nightingale, Mary Livermore and Jane Addams. In Menzel, D. and White, J. (Eds.), The State of Public Administration: Issues Challenges and Opportunities, pp. 36-53. Taylor \& Francis.

Sklar, K. (1995). Florence Kelley \& the Nation's Work: The Rise of Women's Political Culture, 1839-1900. Yale University Press.

Skocpol, T. (1992). Protecting Soldiers and Mothers: The Political Origins of Social Policy in the United States. Harvard University Press.

Stillman II, R. (1998). Creating the American State: The Moral Reformers and the Modern Administrative World They Made. University of Alabama Press.

Stivers, C. (2000). Bureau Men, Settlement Women: Constructing Public Administration in the Progressive Era. University Press of Kansas. 
Stivers, C. (2002/1993). Gender Images in Public Administration: Legitimacy and the Administrative State. Sage Publications.

Stone, A. and Stone, D. (1975). Early development of education in public administration. In Mosher, F. (Ed.), American Public Administration: Past, Present, Future, pp. 11-49. University of Alabama Press.

Swan, W. (1995). Breaking the Silence: Gay, Lesbian, and Bisexual Issues in Public Administration. American Society for Public Administration.

U.S. Merit System Protection Board (2011). Women in the Federal Government: Ambitions and Achievements. https://www.mspb.gov/studies/studies/Women_in_the_Federal_Government_Ambitions and_Achievements_606214.pdf.

Wayman, A., Alexander, S. and Shields, P. (2022). Women in Texas local government: the road to city manager. In Shields, P. and Elias, N. (Eds.), Handbook on Gender and Public Administration. Cheltenham, UK and Northampton, MA, USA, Edward Elgar Publishing.

Wilson, W. (1887). The study of administration. Political Science Quarterly, 2(2), 197-222. 